\title{
Facial scanning as an element in the implant treatment planning of full edentulous patient
}

\author{
Scanarea facială: element adjuvant în planificarea tratamentului \\ implanto-protetic al edentatului total
}

\author{
Marina Imre', Mihaela Pantea', Paula Perlea ${ }^{1}$, Anca Nicoleta Temelcea², \\ Ana Maria Cristina Tâncu ${ }^{1}$ \\ ${ }^{1}$ Facultatea de Medicină Dentară, Universitatea de Medicină şi Farmacie \\ "Carol Davila", Bucureşti, România \\ ${ }^{2}$ Facultatea de Moaşe şi Asistență Medicală, Universitatea de Medicină şi Farmacie \\ „Carol Davila“, Bucureşti, România
}

\begin{abstract}
Introduction. The implant-prosthetic rehabilitation of the full edentulous patient implies the complete rehabilitation of the functions of the dento-masticatory apparatus, and the first step is a judicious planning of the treatment. In addition to classical analysis, facial scanning, a newly introduced imaging method, can bring precious information into the planning of this treatment, or by referring to the soft parts essential to restoring the aesthetic function.

Material and methods. A batch of 10 bimaxilary full edentulos patients was consisted; patients' whose medical files were analyzed in a first phase. Following the clinical and complementary evaluation, a patient who met all inclusion criteria was selected in the second phase and decided to carry out facial scanning with the Planmeca Pro Face 3D application in addition to classical implant insertion investigations.

Results and discussions. Facial scanning with Planmeca Pro Face 3D has generated a complex image resulting from triad association - soft parts, bone supply, prefiguration of future dental archways (CBCT with radio-opaque teeth), essential elements in high-implant prosthetic treatment planning of difficulty and high aesthetic requirements. The method has limitations on patient positioning and image compatibility with CBCT images.

Conclusions. Facial scanning is an imaging method of interest in planning implanto-prosthetic treatment. Its introduction into the standard planning protocol for total implantation edentation treatment requires further studies in terms of image calibration precision.
\end{abstract}

Keywords: full edentulism, dental implants, facial scanning

\begin{abstract}
REZUMAT
Introducere. Reabilitarea implanto-protetică a edentaţiei totale presupune reabilitarea integrală a funcţiilor aparatului dento-masticator, iar primul pas îl reprezintă o planificare judicioasă a tratamentului. Pe lângă elementele clasice de analiză, scanarea facială, metodă imagistică nou introdusă, poate aduce informaţii preţioase în planificarea acestui tratament, respectiv prin raportarea la părţile moi, esenţiale în reabilitarea funcţiei estetice.

Material şi metodă. S-a constituit un lot de 10 pacienţi edentaţi total bimaxilar, al căror dosar medical a fost analizat într-o primă fază. În urma evaluării clinice şi paraclinice, în a doua fază a fost selectat un pacient care a corespuns tuturor criteriilor de includere şi pentru care s-a hotărât să se efectueze, pe lângă investi-gaţiile clasice pentru inserarea de implante, şi scanarea facială cu aplicaţia Planmeca Pro Face 3D.

Rezultate şi discuţii. Scanarea facială cu Planmeca Pro Face 3D a generat o imagine complexă - rezultată din asocierea triadei părţi moi, ofertă osoasă, prefigurare a viitoarelor arcade dentare (prin CBCT cu dinţi radioopaci), elemente esenţiale în planificarea tratamentului implanto-protetic cu grad crescut de dificultate şi exigenţe estetice ridicate. Metoda are limitări legate de poziţionarea pacientului şi compatibilizarea imagi-nilor cu imaginile CBCT.

Concluzii. Scanarea facială este o metodă imagistică de interes în planificarea tratamentului implanto-protetic. Introducerea acesteia în protocolul standard de planificare al tratamentului edentaţiei totale prin implanturi necesită studii ulterioare din punct de vedere al preciziei calibrării imaginilor.
\end{abstract}

Cuvinte cheie: edentaţie totală, implante, scanare facială 


\section{INTRODUCERE}

Tratamentul edentaţiei totale reprezintă, prin complexitatea sa, o adevărată provocare pentru medicul stomatolog. Acesta a evoluat odată cu introducerea implantologiei în practica curentă stomatologică prin oferirea unor tehnici de tratament pe implante - protezare fixă sau mobilă - ca alternativă la proteza totală convențională.

Astfel, reabilitarea funcțiilor aparatului dentomasticator prin terapie implanto-protetică, în mod integral - masticație, fizionomie şi fonație - este din punct de vedere protetic, dar şi chirurgical, un procedeu terapeutic cu un grad ridicat de dificultate care necesită o analiză şi o planificare minuțioase.

În succesul acestui tip de tratament, pe lângă examinarea clinică riguroasă, un rol deosebit de important îl dețin tehnicile de investigație imagistică (1).

Până recent, aceste evaluări generau reprezentări bidimensionale ale regiunii maxilo-faciale, fără informații privind părțile moi faciale, importante în desăvârşirea dezideratului estetic (2).

Introducerea noilor tehnici imagistice de tip CBCT în practica curentă oferă o imagine tridimensională a maxilarelor, permitând planificarea poziției inserării implantelor cu mare exactitate atât din punct de vedere al volumului osos, al reperelor anatomice, cât şi al densităţii osoase, spre deosebire de tehnicile bidimensionale de tipul ortopantomografiei sau al teleradiografiei de profil (3). Totuşi, aceasta din urmă prezintă, aşa cum am arătat într-o lucrare anterioară, avantajul de vizualizare într-o singură imagine a contururilor osoase în relație cu părțile moi, iar în cazul efectuării sale cu proteze cu dinţi radioopacizați, chiar raportul acestora cu prefigurarea viitoarelor arcade dentare - bidimensional $(4,5)$, element deosebit de important în vederea inserării implantelor în poziție optimă din punct de vedere protetic.

Obiectivul materialului următor este de a prezenta o nouă tehnică imagistică de planificare a tratamentului protetic - scanarea facială şi, respectiv, suprapunerea acestei imagini peste CBCT, în vederea inserării implantelor în raport optim cu triada structuri osoase, părți moi, viitoare arcade dentare tridimensional de această dată şi cu grad de precizie ridicat.

\section{MATERIAL ŞI METODĂ}

În vederea exemplificării tehnicii imagistice de scanare facială, a fost constituit un lot de 10 pacienți edentați total bimaxilar cu vârste cuprinse între 55 şi 75 ani, 5 pacienţi de sex feminin, 5 de sex masculin. Dosarul medical a cuprins anamneza, examenul clinic intra şi extra oral, modele de studiu, fotografii de diagnostic intra şi extraorale din normă frontală şi laterală. Din punct de vedere imagistic, a fost efectuat CBCT de maxilar. Dosarul de evaluare a cuprins şi un chestionar de 10 întrebări de tip VAS (Visual Analogue Scale), menit să reliefeze gradul de interes estetic al pacienților în raport cu reabilitarea funcției fizionomice.

În urma coroborării datelor analizate, a fost selectat un pacient de sex masculin în vârstă de 72 de ani, fără afecțiuni generale asociate. Criteriul final al selectării acestui pacient în urma analizei lotului a fost legat de particularitatea cazului de asociere a tuturor elementelor de interes în planificarea tratamentului implanto-protetic, respectiv ofertă osoasă, cerințe estetice ridicate şi protezare fixă pe implanturi a maxilarului superior solicitată şi posibil de efectuat din punct de vedere al stării generale de sănătate şi al costurilor.

Prima etapă clinică a constat în efectuarea a două proteze totale convenționale cu dinţi radioopaci, ca prefigurare a relațiilor intermaxilare de ocluzie corecte - în vederea efectuării CBCT-ului diagnostic cu protezele aplicate pe câmpul edentat total, astfel încât să procedăm la planificarea poziției de inserare a implantelor din punct de vedere protetic în raport optim cu viitoarele arcade dentare. Simularea poziționării implantelor şi dimensiunea acestora au fost ghidate de examinarea clinică

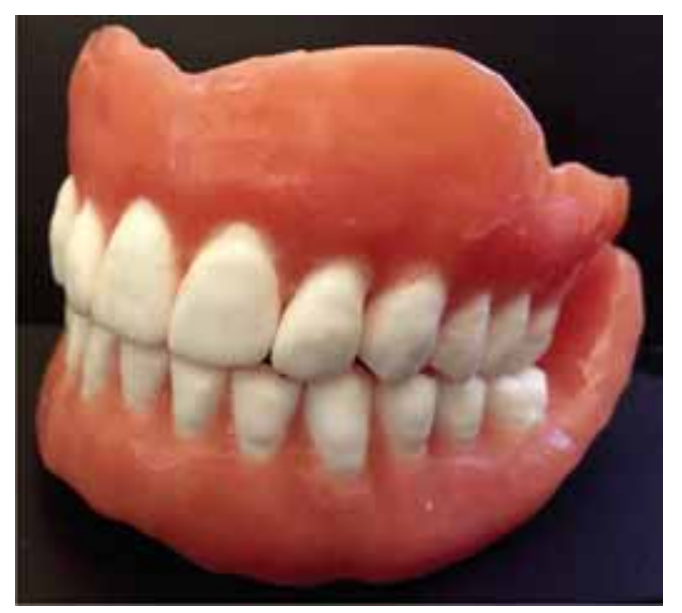

FIGURA 1. Proteze totale convenționale cu dinți radioopaci 


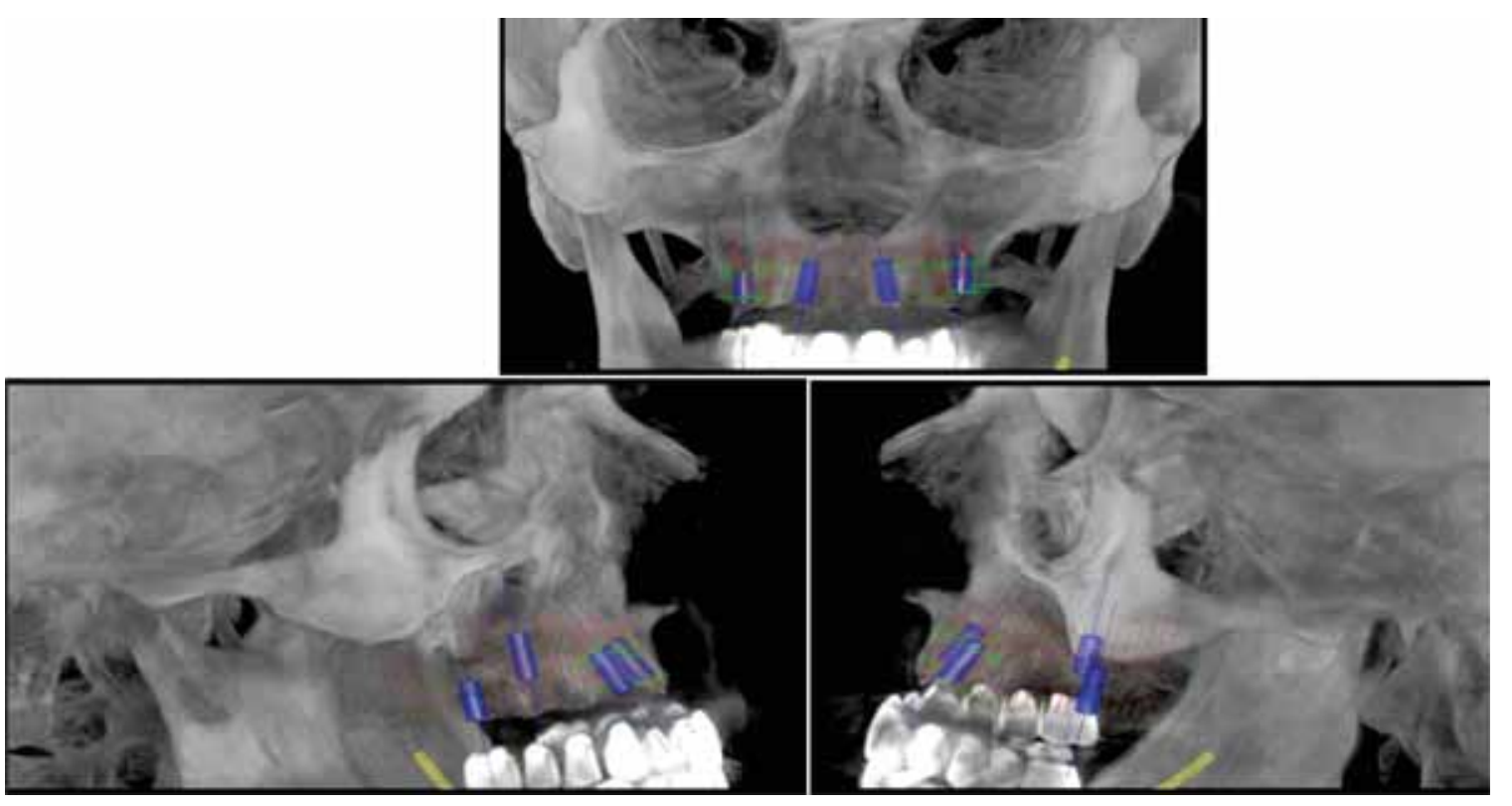

FIGURA 2. Simularea inserării implantelor pe CBCT cu protezele aplicate

coroborată cu biblioteca de implanturi a aplicației Implant Studio (Fig. 1, Fig. 2).

Următoarea etapă a constat în realizarea scanării faciale cu Planmeca Pro Face 3DÒ. Tehnologia de scanare constă într-un sistem prevăzut cu o cameră video capabilă să înregistreze tridimensional geometria facială peste care suprapune o imagine foto a texturii pielii într-o singură expunere, ceea ce permite redarea cu acuratețe a părților moi faciale atât din normă laterală, cât şi din normă frontală. Scanarea se realizează cu pacientul poziționat cu Orizontala de la Frankfurt paralelă cu podeaua şi cu buzele în contact uşor. Scanarea facială nu emite niciun fel de radiații cu potențial dăunător pentru pacienți.

Medicul stomatolog poate evalua astfel, încă din etapa de planificare preoperatorie, anatomia feței cu ajutorul aplicației Planmeca Romexis, care facilitează o analiză detaliată şi îmbunătățeşte rezultatele estetice.

În etapa ulterioară, s-au suprapus imaginile CBCT cu fotografia 3D a pacientului generându-se astfel într-o singură imagine triada esenţială în planificarea tratamentului implanto-protetic - ofertă osoasă, contur părți moi şi prefigurarea viitoarelor arcade dentare.

\section{REZULTATE ŞI DISCUŢII}

Planificarea tratamentului implanto-protetic prin suprapunerea imaginilor rezultate din tehnicile de analiză prin $\mathrm{CBCT}$ - cu planificarea poziționării şi a dimensiunii şi posibilitatea încărcării imediate a implantelor (prin analiza densității osoase) cu analiza facială generată de scanarea facială au condus la realizarea unui plan de tratament complex, coerent care asigură, pe de-o parte, comunicarea cu pacientul şi acceptarea tratamentului propus, iar pe de altă parte, pentru medic, creşterea şanselor de reuşită ale unui tratament $\mathrm{cu}$ grad de dificultate crescut. Metoda realizării CBCT-ului cu proteze cu dinți radioopaci, prin ascocierea cu tehnicile CAD CAM, poate conduce direct la realizarea unui ghid chirurgical în vederea inserării implantelor prin tehnici chirurgicale minimum invazive.

Astfel, s-a hotărât aplicarea a 4 implante la maxilarul superior şi o supraprotezare pe implante solidarizate prin sistem tip bară în vederea susținerii părților moi faciale, colabate prin resorbția accentuată a versantului vestibular (Fig. 3, 4, 5).

Sistemul introduce o unitate integrată 3D care generează o imagine reală 3D facială, în plus față de radiografia maxilofacială digitală tradiţională. $\mathrm{O}$ singură scanare generează atât o imagine $3 \mathrm{D}$, cât şi o imagine CBCT. Alternativ, imaginea 3D poate fi achiziţionată separat printr-un proces complet fără radiaţii: laserele scanează geometria facială, iar camerele digitale captează textura de culoare a feței.

Acest studiu a fost realizat în vederea aprecierii oportunitățiilor oferite de integrarea scanării faciale în protocolul de planificare a tratamentului implanto-protetic al edentatului total. Rezultatele au demonstrat obținerea unor imagini prin ale căror 

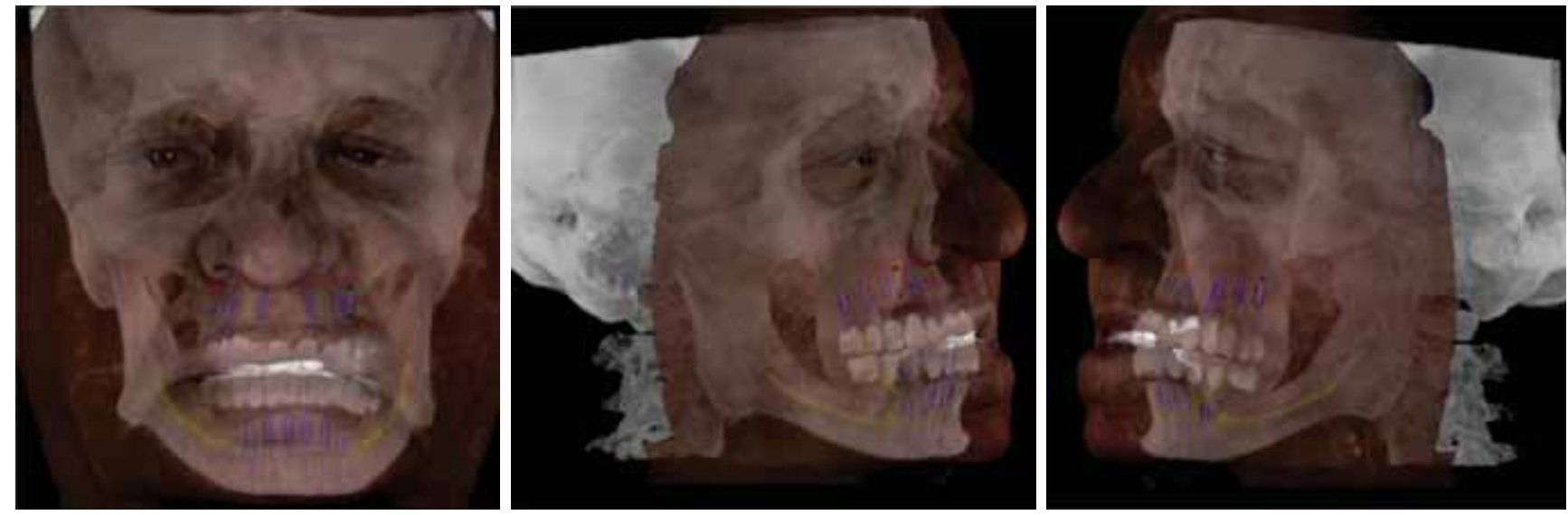

FIGURILE 3, 4, 5 Scanarea facial suprapusă peste CBCT din normă frontală şi laterală

măsurători, ajustări şi suprapuneri sunt generate o multitudine de date şi parametri utili în terapia edentației totale la pacienţi cu aşteptări estetice ridicate.

Totuşi, această metodă are, actualmente, câteva limitări. Prima este problema de precizie în integrarea diferitelor tipuri de date înregistrate. Integrarea înregistrării ocluzale în scanarea facială depinde de vizibilitatea suprafețelor vestibulare ale dinților maxilari. Altă problemă este reprezentată de factorii legaţi de pacient, inclusiv mişcarea în timpul scanării, fluxul salivar şi părul facial, care pot influența, de asemenea, precizia procedurii de scanare şi înregistrare (6).

Autorii au identificat relativ puține articole publicate despre valoarea integrării tehnologiei faciale de scanare în practica stomatologică $(7,8)$. Cel mai cunoscut studiu aparține lui Rangel et al., care prezintă conceptul de integrare a radiografiilor dentare digitale cu scanări faciale extraorale.

\section{CONCLUZII}

Planificarea tratamentului în edentația totală reabilitată prin terapie implanto-protetică este esențială în asigurarea succesului pe termen lung, iar evaluarea diagnostică trebuie să includă obligatoriu

\section{BIBLIOGRAFIE}

1. Juodzbalys G., Wang H.L.Guidelines for the Identification of the Mandibular Vital Structures: Practical Clinical Applications of Anatomy and Radiological Examination Methods. J. Oral Maxillofac. Res. 2010; 1(2).

2. Hassan B., Gimenez Gonzalez B., Tahmaseb A., Greven M., Wismeijer D. A digital approach integrating facial elemente şi informații complete atât asupra elementelor protetice (prefigurarea arcadelor dentare), cât şi al ofertei osoase coroborate cu informații asupra părților moi şi al profilului pacientului edentat total.

În acest sens, scanarea facială oferă informații utile, asigurând intervenții minimum invazive cu rezultate estetice de înalt nivel. Aplicaţia este concepută pentru a satisface cele mai diverse nevoi de diagnosticare şi documentare pre şi post operatorii atât ale medicilor stomatologi, cât şi ale specialiştilor în chirurgia orală sau maxilo-facială.

În mod evident, sunt necesare studii suplimentare asupra tehnicii de scanare facială şi a validării acesteia. Introducerea unor noi tehnologii în practica zilnică oferă practicianului avantajul unor tratamente cu rezultate predictibile, îmbunătăţeşte comunicarea cu pacientul şi gradul de acceptabilitate al tratamentului, dar, pe de altă parte, necesită un proces continuu de educaţie medicală, precum şi însuşirea acestor noi tehnici imagistice computerizate ca instrument de lucru cotidian.

\section{Notă}

Toți autorii au avut contribuții egale în realizarea acestui articol.

Conflict of interest: none declared Financial support: none declared

scanning in a CAD/CAM workflow for full mouth implants supported rehabilitation of the edentulous patient: A pilot clinical study. J Prosthet Dent 2016

3. Joda T., Gallucci G.O. The virtual patient in dental medicine. Clin Oral Implants Res 2015; 26:725-6. 
4. Melescanu-Imre M., Preoteasa E., Tâncu A.M., Preoteasa C.T. Imaging technique for the complete edentulous patient treated conventionally or with mini implant overdenture, JML, Vol VI, Issue 1, March 2013

5. Draghici R., Preoteasa E., Preoteasa C.T., MelescanuImre M. Cranio-facial and soft tissue characteristics of edentulous patients. Preliminary results. Current Health Sciences Journal, Vol. 39, No. 4, Supliment 12, 2013

6. Hassan B., Giménez Gonzáles B., Tahmaseb A., Jacobs R., Bornstein M.M. Three-dimensional facial scanning technology: applications and future trends. Forum Implantologicum 2014:10:77-86.
7. Rangel F.A., Maal T.J., Bergé S.J., van Vlijmen O.J., Plooij J.M., Schutyser F., Kuijpers-Jagtman A.M. Integration of digital dental casts in 3-dimensional facial photographs. Am J Orthod Dentofacial Orthop 2008; 134:820-6.

8. Rosati R., De Menezes M., Rossetti A., Sforza C., Ferrario V.F. Digital dental cast placement in 3-dimensional, full-face reconstruction: a technical evaluation. Am J Orthod Dentofacial Orthop 2010; 138:84-8. 